\title{
Circuit
}

Musiques contemporaines

\section{In nomine Zappa, Zappatore}

Sketch of an Hypothesis $\left(\mathrm{S} / \mathrm{Z}^{2}\right)+(\mathrm{sv} / \mathrm{gw})$

In nomine Zappa, Zappatore

Esquisse d'une hypothèse $\left(\mathrm{S} / \mathrm{Z}^{2}\right)+(\mathrm{sv} / \mathrm{gw})$

\section{John Rea}

Volume 14, numéro 3, 2004

Frank Zappa : 10 ans après

URI : https://id.erudit.org/iderudit/902330ar

DOI : https://doi.org/10.7202/902330ar

Aller au sommaire du numéro

Éditeur(s)

Les Presses de l'Université de Montréal

ISSN

1183-1693 (imprimé)

1488-9692 (numérique)

Découvrir la revue

Citer ce document

Rea, J. (2004). In nomine Zappa, Zappatore: Sketch of an Hypothesis $\left(\mathrm{S} / \mathrm{Z}^{2}\right)+$ (sv/gw). Circuit, 14(3), 103-112. https://doi.org/10.7202/902330ar
Résumé de l'article

" Le caractère de l'homme, observa Héraclite, fait son destin. » De la même façon, Frank Zappa a noté qu'on est ce qu'on fait (You are what you is). In nomine Zappa, Zappatore propose une déconstruction, à la fois philologique et iconographique, du nom italien / masque (persona), Zappa. L'article suggère que, non seulement le caractère d'un homme est son démon mais aussi que FZ était un ouvrier artistique assidu et subversif.
Tous droits réservés @ Les Presses de l’Université de Montréal, 2004

Ce document est protégé par la loi sur le droit d'auteur. L'utilisation des services d'Érudit (y compris la reproduction) est assujettie à sa politique d'utilisation que vous pouvez consulter en ligne.

https://apropos.erudit.org/fr/usagers/politique-dutilisation/ 


\title{
In nomine Zappa, Zappatore Sketch of an Hypothesis $\left(S / Z^{2}\right)+($ sv/gw)
}

\author{
John Rea
}

Man's character is his daimon.

The character of a man is his destiny.

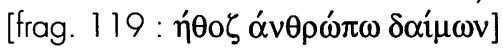

Heraclitus

\section{'Ouverture filologica zappesca'}

Etymologies

\begin{tabular}{|c|c|c|c|c|}
\hline $\begin{array}{l}\text { Latinus } \\
\text { (tardus) }\end{array}$ & Italiano & Français & English & Deutsche \\
\hline \multirow[t]{3}{*}{ sappa(m) } & $\begin{array}{l}\text { Zappa } \\
\text { Zappone } \\
\text { Zappata }\end{array}$ & $\begin{array}{l}\text { hove } \\
\text { (mil.) sape } \\
\text { pioche } \\
\text { coup de pioche }\end{array}$ & $\begin{array}{l}\text { Hoe } \\
\text { (mil.) sap, trench } \\
\text { mattock, pickax(e) } \\
\text { whack, chop of } \\
\text { the pickax }\end{array}$ & $\begin{array}{l}\text { Hacke, Haue } \\
\text { (mil.) Sappe } \\
\text { Karst, Spitzhacke } \\
\text { Der Hack, Schlag } \\
\text { der Haue }\end{array}$ \\
\hline & $\begin{array}{l}\text { Zappare } \\
\text { zappa }\left(3^{\circ} \text { pers. sing.) }\right. \\
\text { Zapponare }\end{array}$ & $\begin{array}{l}\text { hover, cultiver, } \\
\text { saper, miner } \\
\text { II hove; il sape. } \\
\text { piocher }\end{array}$ & $\begin{array}{l}\text { to dig, to till soil, } \\
\text { to sap, to undermine } \\
\text { He hoes; he saps. } \\
\text { to dig with a mattock }\end{array}$ & $\begin{array}{l}\text { hacken, Ackerbau treiben, } \\
\text { sappieren, unterminieren } \\
\text { Er häckt; er sappiert. } \\
\text { das Erdreich bearbeiten }\end{array}$ \\
\hline & $\begin{array}{l}\text { Zappatore } \\
\text { (mil.) genio di } \\
\text { zappatori }\end{array}$ & $\begin{array}{l}\text { terrassier } \\
\text { paysan } \\
\text { (mil.) sapeur(s) }\end{array}$ & $\begin{array}{l}\text { Digger } \\
\text { peasant, farmer } \\
\text { (mil.) corps of sapers }\end{array}$ & $\begin{array}{l}\text { Gräber, Schipper, (Hacker) } \\
\text { Bauer } \\
\text { (mil.) Pionier }\end{array}$ \\
\hline
\end{tabular}




\begin{tabular}{|c|c|c|c|c|}
\hline Latinus & Español & Italiano & Français & English \\
\hline sapa & (fig.) savia & $\begin{array}{l}\text { vino nuovo } \\
\text { (fig.) linfa }\end{array}$ & $\begin{array}{l}\text { nouveau vin (vin réduit) } \\
\text { (fig.) sève }\end{array}$ & $\begin{array}{l}\text { new wine (plant juice) } \\
\text { (fig) sap, (pejor.) saphead }\end{array}$ \\
\hline vappa(m) & & $\begin{array}{l}\text { vappa } \\
\text { (fig.) privo di buon senso } \\
\text { sciocco, imbecile } \\
\text { vanesio, briccone }\end{array}$ & $\begin{array}{l}\text { mauvais vin; vin éventé } \\
\text { vin affaibli } \\
\text { (fig.) niais, sot, bête } \\
\text { vaurien, gredin } \\
\text { fat, coquin }\end{array}$ & $\begin{array}{l}\text { bad wine, sour wine } \\
\text { weak wine } \\
\text { (fig.) lacking in good sense } \\
\text { good-for-nothing, fool } \\
\text { fop, rascal }\end{array}$ \\
\hline & guapo & (dial. Napol.) guappo & $\begin{array}{l}\text { Audacieux, dandy } \\
\text { belle canaille } \\
\text { Matamore, fanfaron } \\
\text { petite brute, sicaire } \\
\text { gouape, voyou, rital }\end{array}$ & $\begin{array}{l}\text { audacious, dandy } \\
\text { handsome rogue } \\
\text { braggart, cocky } \\
\text { bully, thug } \\
\text { (Amer. slang) wop, (woppa) }\end{array}$ \\
\hline
\end{tabular}

Homonymy (homophony), paronymy

\begin{tabular}{|c|c|c|}
\hline English (20th C. slang, jargon) & Italiano & Français \\
\hline $\begin{array}{l}\text { letym. : onomat., gun fire, } \\
\text { sudden action) } \\
\text { zap [!] }\end{array}$ & & $\begin{array}{l}\text { tonus, entrain } \\
\text { paf! (exclam.) }\end{array}$ \\
\hline $\begin{array}{l}\text { to zap (transitive) } \\
\text { zapped } \\
\text { (also hacker slang) }\end{array}$ & & $\begin{array}{l}\text { détruire, tuer } \\
\text { tirer sur } \\
\text { assommer } \\
\text { traiter (au laser; à microondes; irradier) } \\
\text { supprimer (inform.) } \\
\text { piquant, épicé } \\
\text { (aussi argot, pirates informatiques) }\end{array}$ \\
\hline to zap (intransitive) & & faire un saut, pitonner, zapper (télé.) \\
\hline zapping & uso frenetico del telecomando & zapping, pitonnage (télé.) \\
\hline $\begin{array}{l}\text { zapper (also slang pronunciation } \\
\text { on the model, gangster- gangsta, } \\
\text { rapper-rappa, } \\
\text { hence, zapper-zappa) }\end{array}$ & & $\begin{array}{l}\text { télécommande } \\
\text { (II existe gangster, raplpleur, } \\
\text { mais non pas zaplpleur.) }\end{array}$ \\
\hline
\end{tabular}


Expressions, sayings, 'dictons'

\begin{tabular}{|c|c|c|}
\hline Italiano & Français & English \\
\hline Darsi la zappa sui piedi & $\begin{array}{l}\text { se donner un coup de hove sur } \\
\text { les pieds (donner des verges } \\
\text { pour se faire fovetter ; scier la } \\
\text { branche sur laquelle on est assis) }\end{array}$ & $\begin{array}{l}\text { to defeat one's own ends, } \\
\text { to rap one's own knuckles }\end{array}$ \\
\hline Zappare quattrini, denari & $\begin{array}{l}\text { Houer les sous, l'argent, comme } \\
\text { si on l'extrait de la terre }\end{array}$ & to make money \\
\hline Zappare nell'acqua, nella sabbia & $\begin{array}{l}\text { Hover dans l'eau, dans le sable } \\
\text { (travailler sans succès) }\end{array}$ & to build castles in the air \\
\hline Stare coi frati e zappare l'orto & $\begin{array}{l}\text { Rester avec les moines et hover } \\
\text { le potager (se plier, aux } \\
\text { décisions des dirigeants dans } \\
\text { une entreprise) }\end{array}$ & $\begin{array}{l}\text { Stay at home with the monks and } \\
\text { mind the garden }\end{array}$ \\
\hline Non suona il pianoforte, lo zappa & $\begin{array}{l}\text { il ne joue pas du piano, il hove, } \\
\text { il pioche }\end{array}$ & he doesn't play piano, he stabs it \\
\hline \multirow[t]{5}{*}{$\begin{array}{l}\text { Riede alla sua parca mensa, } \\
\text { fischi-ando, il zappatore' }\end{array}$} & $\begin{array}{l}\text { il retourne à son maigre repas, } \\
\text { en sifflant, le paysan }\end{array}$ & $\begin{array}{l}\text { He comes home to his meagre } \\
\text { dinner, whistling, the peasant }\end{array}$ \\
\hline & $\begin{array}{l}\text { Je peux reconnaître des ritals de } \\
\text { loin }\end{array}$ & $\begin{array}{l}\text { Wops, said Boyle, I can tell } \\
\text { wops a mile off. }{ }^{2}\end{array}$ \\
\hline & $\begin{array}{l}\text { Les pilotes laissent entendre que } \\
\text { les ritals étaient trouillards, qu'ils } \\
\text { ne pouvaient pas voler à travers } \\
\text { les nuages }\end{array}$ & $\begin{array}{l}\text { The pilots ... suggested that } \\
\text { 'Wops were yellow' or that they } \\
\text { could not 'take it through cloud'3 }\end{array}$ \\
\hline & $\begin{array}{l}\text { Recalibrer à six le niveau } \\
\text { d'analyse, ef recommencer }\end{array}$ & $\begin{array}{l}\text { zap the debug level to } 6 \text { and run } \\
\text { it again }\end{array}$ \\
\hline & $\begin{array}{l}\text { je pense que cet éclair a supprimé } \\
\text { le contrôleur du disque dur }\end{array}$ & $\begin{array}{l}\text { I think that lightning bolt may } \\
\text { have zapped the disk controller }\end{array}$ \\
\hline
\end{tabular}

1. LEOPARDI, G. (1953), "Il sabato del villaggio" (1 829), lines 28-29, Canti, Rizzoli, Milano, p. 101.

2. HEMINGWAY, E. (1925), In Our Time, New York, Scribners, p. 17.

3. (1942), Royal Air Force Journal, 26 June, London, Eyre and Spottiswoode, p. 63.

4. See ZAPPA, F. and OCCHIOGROSSO, P. (1989), The Real Frank Zappa Book, New York, Poseidon Press. At page 15: "My real name is Frank Vincent Zappa (not Francis - I'll explain it later)." At page 245:

"I was in my mid-twenties when I found out! Up until the time I had to get a passport for the first European tour [1967], I thought my name was Francis - a name I had always hated. In order to get the passport, I had to present my birth certificate - a mysterious document I had never seen before. My mother mailed it to me from California, and on it, much to my delight, was a name OTHER THAN FRANCIS [emphasis by FZ] well it wasn't that good - 'Frank' isn't much of a bargain - but I had thought for years, even printing it on album covers, that I was Francis Vincent Zappa Junior. How could I be such a fool?)." FZ's father was Sicilian of Greek heritage; his mother of French/Italian origin. The name, Francesco (Francis), is an adjectival form meaning Frankish, or, related to France. Had FZ been named Franco la 'Frank'), Francis would be a normal equivalent in English, less so, Frank. FZ's father may have originally been named Franco.

\section{Thesis One}

\section{Italianess (Italianité) - What's in a name - Paths to unrealized destinies}

In America, had FZ, born in 1940 as Frank Vincent Zappa - believing until about 1966 nevertheless that his first name was actually Francis ${ }^{4}$ - removed his mask (persona) of Italianess (Italianité) early on in life, he might have become any number of self-made men:

F. Vincent Mattock, corporation lawyer, or

Vinnie Saper, head coach of the Baltimore Boars, or

Franz V. Schipper, vice-president (marketing), or

Effvie Hacker, computer consultant. 
But FZ does not really tamper with his mask nor does he try to make the one he has more beautiful. He does not do like the patriarch of Italian-American literature from the early nineteenth century, Emanuele Conegliano, professor of Italian language and literature and department head at Columbia University, better known in the late eighteenth century as Lorenzo Da Ponte, librettist to Mozart.

FZ does not become Francesco Zappa (cf. FZ's recording (1984) of the music of Francesco Zappa (1763-1788), cellist and composer), that is, he does not cross over into Italianess (Italianité) like soprano Marie Lovise Cécile La Jeunesse (18471930), born at Chambly (Quebec) but who had lived in Plattsburgh and Albany (New York). The debut of her operatic career in 1870 at Messina (Sicily, not New York/ was also accompanied by a new name, Emma Albani, chosen for her by an Italian impresario, after an old distinguished family, a name she thought was predestined: she had already lived in 'Albany'.

Although FZ truncates his name to two letters, he does not shorten the family name, say to Zapp, similar to American composer and author of pedagogical books, Walter Piston (1894-1976), born Pistone, the grandson of an Italian seaman. FZ hated the name Francis ('Fran', 'sis', 'sissy'), for no boy born with that name could ever possibly live with it especially after Francis the Talking Mule (1949). The first in a popular post-War film series ended the use of the name for generations. The story: in Burma, a very intelligent mule befriends a soldier ${ }^{5}$ helping him become a war hero, whereupon he is treated like a lunatic for trying to show that Francis talks. $F Z$, in his own way, becomes 'lunatic'. In Christian hagiography, Francis of Assisi, patron saint of Italy, talks to birds and animals and they talk to him; he also converses with his 'Fratello Sole' and his 'Sorella Luna'. FZ naturally speaks with his daughter, Moon Unit.

Nor does FZ adopt an entirely new name like American guitarist Eddie Lang, born Salvatore Massaro (1902-33), and also known as Blind Willie Dunn. Massaro became the most sought after New York session player of his day working with the Paul Whiteman Orchestra and later with Bing Crosby.

FZ does not replace his mask nor does he transform his name like so many other artists of his generation. In short, he does not let a potential encumbrance impede his progress; instead he converts a liability into an asset. In the Italian language, the expression for changing one's name within the professional world of art lusing a pseudonym) is nome d'arte, or, in arte, such as in the remark, Robert Zimmerman, in arte Bob Dylan, or, Freddie Mercury, nome d'arte di Farookh Balsara.

Some notable mask adjustments and/or replacements in arte are:

Paul Creston, American composer (Giuseppe Guttoveggio, 1906-85),

Violet Archer, Canadian composer (Violetta Balestreri, 1913-2000)

Dean Martin, popular singer (Dino Paul Crocetti, 1917-95)

Peter Mennin, American composer, head, Julliard School (Peter Mennini, 1923-1983) 
Tony Bennett, popular singer (Antonio Benedetto, 1926-)

Jerry Vale, popular singer (Gennaro Louis Vitaliano, 1932-1

Bobby Darin, popular singer (Walden Robert Cassotto, 1936-73)

James Darren, popular singer and actor Uames William Ercolani, 1936-1

Frankie Valli, popular singer, The Four Seasons (Francis Stephen Castelluccio, 1937-1

Frankie Avalon, popular singer and actor (Francis Thomas Avallone, 1939-)

Dion, popular singer, Dion and the Belmonts (Dion Di Mucci, 1939-)

Bobby Rydell, popular singer (Robert Ridarelli, 1942-)

Fabian, popular singer (Fabiano Forte Bonaparte, 1943-).

David Chase, American television writer, The Sopranos (David De Cesare, 1945-).

Other nomi d'arte for actors, singers and personalities of Italian origin:

Alan Alda (Alfonso D'Abruzzo), Charles Atlas (Angelo Siciliano), Anne Bancroft (Anne Italianol, Lovie Bellson (Luigi Balassone), Nicolas Cage (Nicholas Kim Coppola), Vic Damone (Vito Farinola), Connie Francis (Concetta Franconero), Terence Hill (Mario Girotil), Frankie Laine (Francesco LoVecchio), Mario Lanza (Alfredo Cocozza), Sophia Loren (Sofia Villani Scicolone), Madonna (Madonna Veronica Louise Ciccone), Yves Montand (lvo Levi), Bernadette Peters (Bernadette Lazzaro), Frank Sinatra (Francis Albert Sinatra), Bud Spencer (Carlo Pedersoli), Robert Stack (Robert Modini), Connie Stevens (Concetta Ingolia), Rudolph Valentino (Rodolfo Guglielmi).

\section{Thesis Two}

\section{Iconography - Mirror, Mirror on the Wall - the Z-structure}

As early as 1970, with a photo of his 'scary' and mustached face appearing on a compilation recording ${ }^{6}$ - a photo suggestive of a careful hybridization between Groucho Marx and Che Guevara, if not Emiliano Zapata Mexican revolutionary hero) with rolled bandanna around his neck - large letters are arranged at the top of the album jacket, Zapped. Here, perhaps, is the first commercial attempt to secure a public image for FZ through a quasi-interlingual paronymy that capitalizes upon the family name. The Zappa Family Trust carries this on today in the same vein?

From that moment forward, someone (a 'kidnappa'?, FZ himself?) harnesses the letter $Z$ by means of rhetorical figures, synecdoche and metonymy, but taken visually ${ }^{8}$. Similar in impact to trademark branding, this new conscript, $Z$, digs in deeply. Thus it is quite easy to decipher a new iconographic conceit resident on the cover of FZ's tenth album, Weasels Ripped My Flesh 11970, FZ, Mothers of Invention): a hidden 'charpente' ${ }^{\prime 9}$ in the slant of the smiling man's face, top right to bottom left, i.e., the diagonal of the letter $Z$.

6. WARNER BROTHERS (1970), Zapped, compilation album, PRO 368. For a view of this album cover see, hitp://home.clara.net/ fil/rocksamplers/warner.htm

7. At the following Internet site, one can see all the FZ album covers. http://storesenseO 1 .dynamic.net/zappa/Search. bok? category=Ryko+Releases

8. Earlier, in 1964, FZ renamed a recording studio that he had purchased, Studio $Z$.

9. Cf. BOULEAU, C. (1963), Charpentes, la géométrie secrète des peintres, Paris, Éd. Le Seuil, 269 p. 
This Z-structure with guitar and/or other objects also appears on:

Burnt Weeny Sandwich (1970), 200 Motels (1971), Just Another Band From L.A. [automobile] (1972), Waka / Jawaka [sink bottom] (1972), One Size Fits All [sofa] (1975), Sleep Dirt [a bed] (1979), The Grand Wazoo (1979), Ship Arriving Too Late To Save A Drowning Witch [tangram-like figure] (1982), Shut Up 'n Play Yer Guitar (1982), The Man From Utopia (1983), Jazz From Hell [also a reverse Z: left to right] (1986), Guitar (1988), The Best Band You Never Heard in Your Life [stage light slant] (1991).

The Z-structure with faces (profiles, noses) or body parts (legs, bodies, etc.):

Chunga's Revenge (1970), Zoot Allures (1976), Sheik Yerbouti (1979), Joe's Garage Acts 1, II, and III (1980), You Are What You Is (1981), Baby Snakes (1983), Them Or Us [animal face] (1984), Francesco Zappa - Frank Zappa [same animal face] (1984), Thing Fish (1984), The Yellow Shark (1993).

The Z-structure eventually emerges literally in an S-replacement ${ }^{10}$ : the title of a posthumous recording, Civilization Phaze III (1994) appears as an answer to questions FZ asks on the album We're Only in It for the Money (1968): Is this Phase One of Lumpy Gravy? and on Lumpy Gravy (1967): Is this Phase Two of We're Only in It for the Money? ? $^{11}$
10. This $S / Z$ affectation works well thanks to linguistic tensions between the graphemic and phonemic dimensions of English, both in its British and American varieties. It also evokes the pronunciation defect known in French as 'zézaiement' (verb, 'zézayer'), where ' $S$ ' and 'I' are replaced with ' $Z$ '.

11. I would like to thank Réjean Beaucage for pointing out this example to me.

\section{Thesis Three}

Size matters not. Look at me. Judge me by my size, do you? And well you should not. For my ally is the Force. And a powerful ally it is.

Yoda $^{12}$

The Empire Strikes Back (film, 1980)

\section{Hellenicity of words - S, M, L, XL - American-style}

Musicologist, composer and raconteur, Nicolas Slonimsky writes about an invitation in 1981 from FZ who wanted to meet the author of the Thesaurus of Scales and Melodic Patterns (1947). In his luxurious home located in the Hollywood Hills, "Zappa met me at the door. He looked like a leading man in the movies - tall, slender, sporting a slight [?!] Italian moustache. For starters, I asked him the origin of his last name; he replied it meant 'the plough' [British spelling] in Italian." ${ }^{13}$

Now, hyperbole is also a rhetorical figure that when well employed can make a lasting impression, as we have just read. 'Plow' in Italian is aratro /charrue in French;

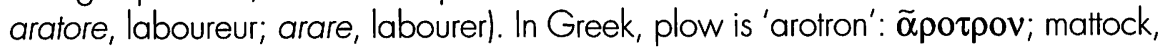

12. Attribution: U. S. screenwriter, Leigh Brackett (1915-1978) with producer George Lucas and Irvin Kershner. The character Yoda is instructing Luke Skywalker in the use of the Force.

13. SLONIMSKY, N. (1988) Perfect Pitch: a life story, New York, Oxford, p. 251. 
pioche, zappone is 'tsopa' or 'tsapa': $\tau \sigma \omega ́ \pi \alpha, \tau \sigma \alpha \dot{\pi} \alpha \alpha$. While the word for hoe, hove, zappa is 'sxalistéri': $\sigma \chi \alpha \lambda \imath \sigma \tau$ ' $\rho \imath$. Curiously, the word for plowman in Greek begins

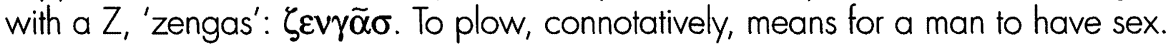

Clearly, size matters. Consider the American slang expression, 'wazoo' which deforms the French word for bird, oiseau ('ornis' in Greek), meaning penis ('zizi' in French, i.e., two Z's, double Z-structure; see below the note on FZ's Questi cazzi...). ${ }^{14}$ Wazoo, which may also refer to anus, is thus another $S / Z$ interlingual replacement word. The Grand Wazoo (Big Bird), FZ's sobriquet for the hard-driving band of twenty musicians that toured with him in September 1972, also welcomed a state of repose (flaccidity?): The Petit Wazoo, a smaller band, toured with him in OctoberDecember 1972. The disk, The Grand Wazoo, appeared in 1972.

In our historical epoch, social commentators concede that, as U. S. economist Veblen so rightly observed as early as 1914, "Invention is the mother of necessity." 15 Verve-MGM Records thought so too: in 1965 in order to avoid censorship problems, the company obliged FZ to change the name of his group, Mothers (1965), formerly Muthers (1964), due to a not so hidden double entendre. This strategy bespoke of a classical conservatism for the band's rebaptised name endorsed the original notion from ancient Greece: "A State, said I [Socrates], arises, as I conceive, out of the needs of mankind" (...) "let us begin and create in idea a State; and yet the true creator is necessity, who is the mother of our invention." 16
14. 'Zizi' is a deformation of 'oiseau' (Petit Robert dictionary, lang. enfantin). Thus 'wazoo' results as a deformation of 'oiseau' pronounced with an American accent (where 'zi-zi' has two Z's not two Zed's). In Italian, 'uccello' (bird) is also slang for penis. In French slang there is also 'zob' (arabic, 'zobb').

15. VEBLEN, T. (1914), The Instinct of Workmanship, New York, B.W. Huebsch, p. 47.

16. PLATO (1930), Republic, P. Shorey, trad., Cambridge, Harvard, book II, 369-C.

\section{Thesis Four}

Enfin la grossièreté de sa bassesse
est poussée jusqu'à chanter (...)
Voltaire
sur l' "Art burlesque"
Dictionnaire philosophique

\section{Doo-wop - Wops are yellow - Doin' wop}

A lexicon of $F Z$ literary (interlingual, scatalogical ${ }^{17}$, etc.) puns and musical invective, were anyone so disposed to publishing it, would be very extensive and range from the silly Sheik Yerbouti (shake your body) to the suave Zoot Allures ('zut, alors' in French', but which may also mean 'allures de Zoot' or 'Soot Allures', that is, may either allude to the glamour of hoodlums and pimps wearing a 'zoot suit' [by paraphrastic homophony with 'zuit suit'], or to FZ's early 1963 band, The Soots ${ }^{19}$ ). Puns and invective have always nourished the belligerence and rebellion of youth, not only in its creative obsession for haberdashery and habiliments - flappers (1920s),
17. PHI ZAPPA KRAPPA are words on FZ's toilet poster. Parodying American fraternitysorority clubs, he creates a macaronic chain of quasi Greek letters, phi ( $\Phi \sim$ F.), Zappa (Z zeta), Krappa (K kappa).

18. 'Zut, alors' is a common French euphemism for the word, merde (shit). This is another interlingual (S/Z) pairing, 'shit' for ' $z u t$ '.

19. Compare the sootcovered face of $F Z$ on Joe's Garage Act I (1979), Joe's Garage Acts II \& III (1979). 
zoot suiters (1930-40s), greasers (1950s), hippies (1960s) - but also in its evolving slang vernaculars about styles in American popular music - jazz, swing, bebop, re-bop, doo-wop, motown, disco, hip-hop, pop, rock, punk, techno, grunge, house, break, rap, smurf, trash, and so forth. Viewed from Europe, such teeming activity has always been explained away as further evidence of the 18th century social theory that certifies Americans (Californians?) as noble savages and 'grands enfants'. The reception in the 1960s, for example, of John Cage's music resembles to a considerable extent the reception provided FZ's music in 1991-93, particularly in his project, The Yellow Shark (Der Gelbe Hai). No one in the 'old country' could remain unaffected by the playful and ironic possibility that, a fortiori, such an evocative patronymic might also mean, The Cowardly Rogue.

Although FZ is portrayed on the album covers, Jazz from Hell (1986) and Broadway the Hard Way (1988), as an urbane musical artisan, elegantly dressed in 'Miami Vice'20 Italian suits (as a 'guappo'), one cannot help but think that even after twenty-five years of career he still wanted to be seen as a handsome old rascal ('vappa') continuing and resolutely pursuing his role as provocative wop, 'to see himself as others saw him'. ${ }^{21}$
20. This popular television crime series of the 1980s also promoted the latest fashion trends for men. FZ had a staring role in episode 41 (second season, broadcast on NBC, March 14, 1986). For more information see: http://wnw.miami-vice.org/episode $/$ episode asp? season $=2 \&$ episode $=41$

21. This is a paraphrase of a line by Scottish poet, Robert Burns: "Oh wad some power the giftie gie us/ To see oursels as others see us!", To a louse (1786), stanza 8.

\section{Hypothesis}

\section{$\left(S / Z^{2}\right)+(s v / g w)=F Z$}

Zappa zappa (Zappa hove, Zappa hoes, Zappa häckt): he works hard. Zappa is also a zappa (il est une sape, he is a trench, Er ist eine Sappe) meaning that, with his zappa (hove, hoe, Hacke), with each and every zappata (coup de pioche, whack of the mattock, Schlag des Karstes), he works as a musical terrorist, a zappatore (sapeur, saper, Pionier). But once the zappatore has completed (as FZ did between 1961-1970) his belligerent and revolutionary zappare (saper, undermining, sappieren), he wishes later to work above ground, simply zappare (cultiver, to till soil, Ackerbau treiben), and with each zappata (coup de pioche, whack of the hoe, Schlag der Have), the aggressive zappatore transforms himself into an eager and rugged zappatore (paysan, farmer, Baver). New tools come into use (after 1970 for FZ), sophisticated tools, bigger tools, industrial tools: size does matter, as we know (GRAND WAZOO, petit wazoo). And so he exchanges his old zappa (hove, hoe, Havel for a zappone (pioche, pickaxe, Spitzhacke) and again works very hard, this time, on himself, convincing the inner self that he's a plow. Said and depicted in a different way -

- zappa Zappa (il cultive Zappa, he tills Zappa, Er ackerbautriebt Zappa), attaining a level in the soil consistency of his creativity where old habits, like old weeds (belligerent negativity), eventually return with the result that zappa Zappa (il sape 
Zappa, he undermines Zappa, Er sappiert Zappa). In fact, Zappa zaps himself, and being zapped, he evolves into a zapper ('zappa'), zapping others along the way by mocking their work (as early as 1968; see the Beatles' spoof in We're Only in It for the Moneyl. Throughout all of this, one knows that he had always enjoyed doo-wop and that, moreover, he frequently gave privilege to songs (e.g. Questi cazzi $^{22}$ di piccione) where he could 'do' wop. This is Commedia dell'Arte whose archetypal masks (maschere) FZ dons invariably with little or no discomfort in his role as social and artistic critic: the rustic, the sponger, the pimp, the sycophant, the buffoon, the rascal, the shrew, the slave, the servant as well as the master.

Let us name the mask that speaks FZ's 'muther' tongue, Zappa, Zappatore.

History has also shown how, before his illness seized him, he had discovered in himself a new sapa, a new organic vitality, a new zest, with zap. Now, as a new zapper (zappa), sensing that he was no longer vappa (weak as sour wine), he zapped (spiced up) his new music, zap!, where once ere fop then guapp' then wop had thundered. But, alas, his time of music ceased...

Zoot! Yet its sounds so urge upon us the sapience that still today we can say.

Non suona la musica, lo Zappa the doesn't play music, he does it FZ's way il ne joue pas de la musique, il en fait à la manière de FZ)

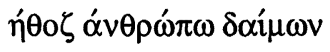

You are what you is ${ }^{23}$

$\left.F Z=\mid S / Z^{2}\right)+(s v / g w)$

Q. E. F.
22. FZ's translation, 'Those Fucking Pigeons', in The Yellow Shark album, is a paraphrase and not literally correct. The Italian word has a familiar ring: revealing two Z's and a double Z-structure, like the French word 'zizi', the vulgar 'cazzo' (plural, 'cazzi') means in English, cock, dick.

23. The song, from the album of the same name, concerns a black man who wants to become white, and a white man who wants to be black. 


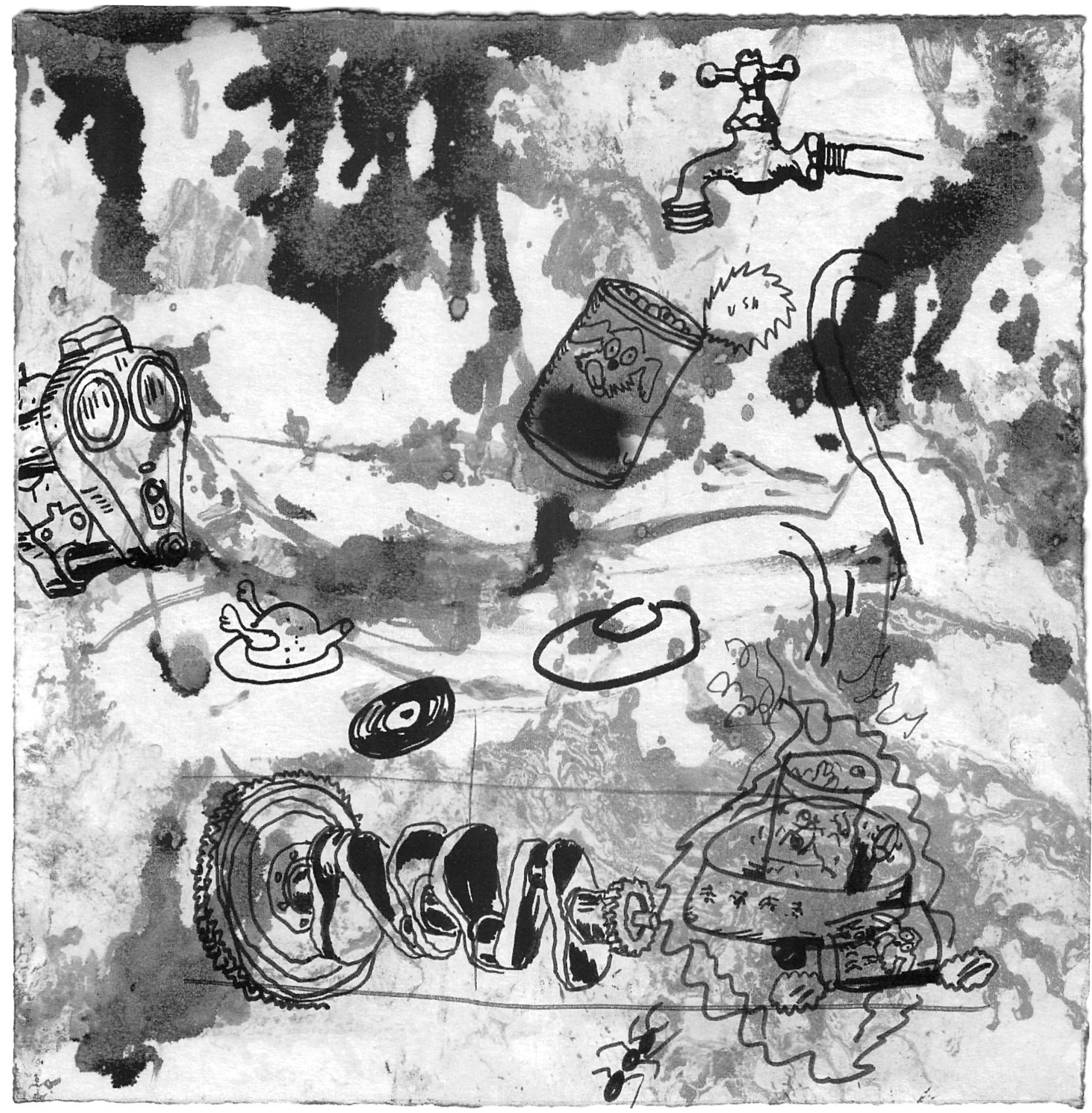

